\title{
Relationships between metal bioaccumulation and metallothionein levels in larvae of Mytilus galloprovincialis exposed to contaminated estuarine sediment elutriate
}

\author{
Alain Geffard ${ }^{1, *}$, Olivier Geffard ${ }^{2}$, Edouard His ${ }^{2}$, Jean-Claude Amiard ${ }^{1}$ \\ ${ }^{1}$ Service d'Ecotoxicologie, SMAB, ISOMer, GDR CNRS 1117, Université de Nantes, 2 rue de la Houssinière, BP 92208, \\ 44322 Nantes Cedex 3, France \\ ${ }^{2}$ IFREMER, Quai du Commandant Silhouette, 33120 Arcachon, France
}

\begin{abstract}
The bioavailability of $\mathrm{Cd}, \mathrm{Cu}$ and $\mathrm{Zn}$ from a metal-contaminated sediment was studied using Mytilus galloprovincialis embryos and larvae exposed to sediment elutriates. The elutriate concentrations tested were always lower than the threshold at which abnormal larval development appears. The $\mathrm{Cd}, \mathrm{Cu}$ and $\mathrm{Zn}$ contents of the sediment, of the elutriate and of the larvae, as well as the larval growth, the condition index (CI), and the induction of metallothionein (MT) in the larvae were measured. The CI was only affected after $96 \mathrm{~h}$ of exposure, principally at the highest elutriate concentration ( $25 \%$, corresponding to $0.1435 \mu \mathrm{g} \mathrm{Cd}^{-1}$ and $\left.14 \mu \mathrm{g} \mathrm{Zn} \mathrm{l}^{-1}\right)$. Cd, Cu and $\mathrm{Zn}$ bioaccumulation was observed (48 and $96 \mathrm{~h}$ ), in whole larvae as well as in the cytosolic fraction of their tissues. For the individual treatments (controls or different degrees of exposure), the lowest metal concentrations were observed in larvae after $96 \mathrm{~h}$ exposure, indicating biological dilution. Metallothionein induction in larvae was observed after $96 \mathrm{~h}$ exposure at the lowest elutriate concentrations tested, and was always strongly correlated with increasing metal contents in the cytosolic fraction. These relationships were significant for all 3 metals studied either individually or combined. The results indicate that these 3 metals are bioavailable to M. galloprovincialis larvae and that MT induction constitutes a more sensitive indicator of heavy metal pollution than embryotoxicity or larval growth experiments.
\end{abstract}

KEY WORDS: Sediment elutriate - Mytilus galloprovincialis larvae - Metal bioaccumulation · Metallothionein

\section{INTRODUCTION}

Micropollutants resulting from anthropogenic activities adsorb to fine particles in the water column. The sedimentation of these particles then creates deposits which constitute micropollutant reservoirs with pollutant concentrations 1000 to 5000 times higher than those in water (Livett 1988). The remobilization of sedimentary micropollutants, either by natural processes

*E-mail: alain.geffard@isomer.univ-nantes.fr (resuspension during tidal movements and periods of high water turbulence) or artificial means (management-related and dredging operations), has been demonstrated in numerous studies (e.g. reviews by Chapman \& Long 1983, Burton 1992).

Concentrations of sediment-associated contaminants alone are inadequate to assess the potential threats to the marine and estuarine environment posed by contaminated sediments. The bioassay is an essential tool for environmental assessment, and embryo-larval tests with marine bivalves (oysters of the genus Crassostrea and mussels of the genus Mytilus) have proved partic- 
ularly sensitive (His et al. 1999). This type of bioassay, first used by Woelke (1972) to evaluate industrial effluents, has also been proposed as a method of quantifying the toxicity of contaminated sediments (Cardwell et al. 1976, Chapman \& Long 1983, Melzian 1990, Hill et al. 1993, Louens et al. 1995, Miller et al. 2000).

Metallothioneins (MT), biomarkers of metal exposure, have come into use recently. MT is a cytosolic protein of low molecular weight that has been shown, both in the laboratory and in situ, to be induced by metal contamination in numerous taxa, including mammals, fishes and marine invertebrates. It is generally recognised that the primary role of MT is the homeostasis of essential metals such as $\mathrm{Cu}$ and $\mathrm{Zn}$. This protein is also involved in the detoxification of non-essential metals such as Ag, Cd and Hg (Roesijadi 1992, Amiard \& Cosson 1997, Cosson \& Amiard, 2000). The use of bivalve MT as a biomarker of metal exposure has been reviewed recently (Langston et al. 1998, Cosson 2000). MT in adult mussels has been proposed as a biomarker of exposure by George \& Olsson (1994) and is used in international biomonitoring programs (UNEP/RAMOGE 1999).

An MT-like protein has also been detected in bivalve larvae. Pavicic et al. (1985) found an induction of protein of low molecular weight similar to the mammalian metallothionein in unfertilized eggs and D-stage larva of Mytilus galloprovincialis after exposure to $0.1 \mu \mathrm{g} \mathrm{Cd}$ $\mathrm{ml}^{-1}$ in seawater. (In M. galloprovincialis, the D-stage larva is the first larval stage attained $48 \mathrm{~h}$ after egg fertilization.) The induction of MT in veliger larvae has been studied in Crassostrea virginica by Ringwood \& Brouwer (1995) and Roesijadi et al. (1995, 1996, 1997), but these studies were based on exposures to experimental doses that were unrealistic compared to environmental concentrations, even in metal-rich areas.

The present study sought to demonstrate the bioavailability of sediment-bound metals to embryos and larvae of Mytilus galloprovincialis. Experiments were carried out using sediment from the Gironde estuary (Atlantic Coast, South of France), which is known to be contaminated by metals (Boutier et al. 1989, RNO 1995, Amiard-Triquet et al. 1998a). On the other hand, low levels of Polycyclic Aromatic Hydrocarbons (<1000 ng g ${ }^{-1}$ : Budzinski et al. 1997), polychlorinated biphenyls (Pierard 1995), and organophosphorous and organonitrogenous compounds (Lartiges 1994) have been recorded in this area. This sediment induced $25 \%$ abnormality in Crassostrea gigas larvae exposed to sediment elutriate (Geffard 2001). In the present study, fertilized mussel eggs were exposed to diluted elutriates (in order to avoid abnormalities) for 48 and $96 \mathrm{~h}$. The bioaccumulation of metals and MT levels was measured in each experimental series at the end of each exposure period.

\section{MATERIALS AND METHODS}

Sediment sampling and storage. Sediment was collected in October 1997 at Le Cheyzin (Gironde estuary, Atlantic coast, South of France). Only oxidized (top $1 \mathrm{~cm}$ ) sediment (about $1.5 \mathrm{~kg}$ ) was removed for sampling, corresponding to the fraction most likely to be resuspended during tidal movements. Desorption studies (Amiard-Triquet et al. 1998a) have shown significant mobility of the metals contained in this sediment.

Aliquots of well-homogenized sediment (500 mg) were immediately prepared for metal analysis, and the remainder was freeze-dried, homogenised and stored in hermetically sealed bottles until bioassays were performed in March 1999. Water content was determined by drying to constant weight at $50^{\circ} \mathrm{C}$, and organic matter content by drying at $70^{\circ} \mathrm{C}$ for $48 \mathrm{~h}$ followed by incineration at $450^{\circ} \mathrm{C}$ for $48 \mathrm{~h}$.

Sediment treatment for analysis and bioassays. Elutriate was obtained by a modification of the method of Melzian (1990). Of the well-homogenized freeze-dried sediment (initial sample $\approx 1.5 \mathrm{~kg}$ ), several samples of $60 \mathrm{~g}$ were weighted, rehydrated, shaken mechanically (multi-wrist shaker, $500 \mathrm{rpm}$ ) in $240 \mathrm{ml}$ of filtered seawater (FSW; $0.2 \mu \mathrm{m}$ filter) and then allowed to settle for $8 \mathrm{~h}$. A portion $(100 \mathrm{ml})$ of the elutriate obtained by siphoning was recovered in an acid-washed polypropylene bottle (Berman et al. 1983) and acidified at 1:1000 by Suprapur hydrochloric acid (Carlo Erba). This portion was stored at $4^{\circ} \mathrm{C}$ in darkness for metal analysis. A second portion was diluted with FSW to test concentrations of 0 (control) 1, 5, 10, and $25 \%$. These concentrations were chosen because previous experiments on the same lyophilised sediment indicated that they did not disturb the embryonic and larval development of Crassostrea gigas (Geffard 2001).

Larval rearing. Mature mussels Mytilus galloprovincialis were collected in the Bay of Arcachon on the day the experiment was performed. Egg-laying was induced by heat shock (alternate immersions in seawater at 16 and $20^{\circ} \mathrm{C}$ ). Females in the laying process were isolated in 11 of FSW, while spawning males were placed in a small amount $(\approx 100 \mathrm{ml})$ of FSW to obtain a sperm-dense solution. The oocytes and sperm of different individuals were observed under an inverted microscope, and the best reproductive pair was selected (regularly shaped female gametes and very mobile spermatozoids) for the experiment. The oocytes were fertilized using $5 \mathrm{ml}$ of the sperm-dense solution. Fifteen minutes after fertilization, the embryos were counted and placed in 21 beakers $\left(60000 \mathrm{l}^{-1}\right)$ filled with the different media to be tested (6 replicates per treatment).

The embryos were incubated at $21 \pm 1^{\circ} \mathrm{C}$ for $48 \mathrm{~h}$ in the presence of the different elutriate concentrations 
tested (6 replicates per treatment) until D-stage larvae were obtained. After incubation, 1 portion (3 replicates) of the larvae was sacrificed for experimental purposes, and the remainder was maintained in rearing conditions for an additional $48 \mathrm{~h}$. In both cases, the weight and mean shell height of veligers were determined according to the technique of His et al. (1983). Size was determined by measuring the length across the valves on photographs; 50 individuals were measured from each culture. The veligers maintained in rearing status were placed in 21 beakers (10000 larvae $\mathrm{l}^{-1} ; 3$ replicates) and fed with cultures of Isochrysis galbana and Chaetoceros calcitrans (50000 cells ml-1 of a mixture of each alga: Helm \& Millican 1977. A condition index (CI) was estimated for each of the rearing categories as follows:

$$
\mathrm{CI}=\frac{\text { mean weight of a lyophilised larva }(\mu \mathrm{g})}{\text { mean shell height of a larva }(\mu \mathrm{m})} \times 100
$$

After counting, the larvae were washed with $0.9 \%$ aqueous ammonium formate isotonic with seawater (elimination of $\mathrm{NaCl}$ : Holland \& Hannant 1973), frozen, lyophilised and stored for chemical and biochemical analysis.

Chemical analysis. Pretreatment of sediments: Aliquots $(0.5 \mathrm{~g})$ of fresh sediment were taken from the well-homogenised total sample and placed in acidwashed glass tubes. These samples were then dried and weighted to determine metal concentration as a function of dry weight. Hot mineralization $\left(95^{\circ} \mathrm{C}\right)$ was performed by addition of $5 \mathrm{ml} \mathrm{HNO}_{3}$ and $3 \mathrm{ml} \mathrm{HCl}$. This process was conducted until dryness, and the residues were then resuspended in $10 \mathrm{ml}$ of $1 \mathrm{~N} \mathrm{HCl}$ for analysis of the metals (Charlou \& Joanny 1983).

Pretreatment of elutriates: The extraction and concentration of metals $(\mathrm{Cd}, \mathrm{Cu}, \mathrm{Zn})$ was performed in FSW (control) and raw elutriate according to the method of Boiteau \& Métayer (1978) as modified by Amiard et al. (1991b). At pH 9, Cd, Cu and Zn were complexed by dithizone in a chloroform phase. However, at $\mathrm{pH} 2, \mathrm{Cd}$ and $\mathrm{Zn}$ enter into acid phase, while $\mathrm{Cu}$ remains in the chloroform phase (Charlot 1966, Irving 1977). Eight ml of ammonium citrate buffer (which increased the $\mathrm{pH}$ from 8.0 to 9.0 ) and $2 \mathrm{ml}$ of dithizone in chloroform solution were added to $100 \mathrm{ml}$ of elutriate or FSW (control) and shaken for $30 \mathrm{~min}$. The FSW (control) or elutriate was then siphoned off, and the dithizone was washed away with deionized water before addition of $1 \mathrm{ml} 1 \mathrm{~N}$ Suprapur hydrochloric acid. At this $\mathrm{pH}(\approx 2)$, the $\mathrm{Cd}$ and $\mathrm{Zn}$ bound to dithizone entered into the acid phase and were analysed, whereas $\mathrm{Cu}$ was measured directly in the dithizonate phase.

Extraction of metals and metallothionein from larvae: The tissue compartmentalization of metals and the partial purification of MT were carried out according to the method described by Mouneyrac et al. (1998). Each replicate of lyophilised larvae was homogenized with a hand-held glass-grinder in $0.02 \mathrm{M}$, Tris-NaCl buffer, $\mathrm{pH} 8.6$, at a ratio of $5 \mathrm{ml}$ buffer $\mathrm{g}^{-1}$ of larvae (wet weight). Proteolytic reactions and the oxidation of MT molecules were avoided by working at $4{ }^{\circ} \mathrm{C}$ with $\beta$-mercaptoethanol (10 $\mathrm{mmol} \mathrm{l}^{-1}$ ) added to the Tris buffer. Cytosolic (S1) and insoluble (P1) fractions were separated by initial centrifugation $(25000 \times g$, 55 min at $4^{\circ} \mathrm{C}$ ). MT was isolated from an aliquot of the $\mathrm{S} 1$ fraction by a second centrifugation $(15000 \times g, 10$ $\min$ at $4^{\circ} \mathrm{C}$ ) after heating for $15 \mathrm{~min}$ at $75^{\circ} \mathrm{C}$. This second (S2) supernatant containing the MT was frozen at $-80^{\circ} \mathrm{C}$ until MT analysis. Before metal analysis, an acid digestion step at $60^{\circ} \mathrm{C}$ was required for the soluble (S1) and insoluble (P1) fractions. This step lasted $12 \mathrm{~h}$ and involved the addition of Suprapur nitric acid (Carlo Erba) at a ratio of 1:1 $\mathrm{S} 1$ supernatant and $1 \mathrm{ml}$ nitric acid per $0.5 \mathrm{~g}$ larvae (P1). The solutions obtained were brought to a known volume $(2 \mathrm{ml})$ with deionized water.

Metal assays: Following the acid digestion phase, metals were analysed by flame atomic absorption spectrophotometry (AAS) for $\mathrm{Cu}$ and $\mathrm{Zn}$, or electrothermal AAS with the Zeeman effect (Hitachi Z8200) for $\mathrm{Cd}$. The analytical method has been described previously by Amiard et al. (1987). Standard addition analysis was performed in an isomedium and the concentrations of each element were $+125,250$ and $500 \mathrm{ng} \mathrm{ml} \mathrm{m}^{-1}$ for $\mathrm{Cu}$ and $\mathrm{Zn}$ and $+0.25,0.5$ and $1 \mathrm{ng}$

Table 1. Results of internal quality control (mean concentrations $\pm \mathrm{SD}$ in $\mathrm{mg} \mathrm{kg}^{-1}$ dry wt) in mussels and sediment. BCR: Community Bureau of Reference

\begin{tabular}{|lccc}
\hline \multicolumn{1}{l}{ Source } & \multicolumn{1}{c}{ Cadmium } & Copper & Zinc \\
\hline Mussel tissue BCR Standard Reference Material 278 R, Sample Identification No. 622 & $9.58( \pm 0.12)$ & $76.2( \pm 0.5)$ \\
Our values & $0.349( \pm 0.013)$ & $9.6( \pm 0.16)$ & $76( \pm 2)$ \\
Certified values & $0.34( \pm 0.002)$ & & \\
Standard marine sediment homogenate SD-M-2/TM IAEA MONACO & & $71.8( \pm 2.25)$ \\
Our values & $0.127( \pm 0.003)$ & $28.7( \pm 0.3)$ & $74.8(72.0-78.3)$ \\
Certified values & $0.113(0.108-0.149)$ & $32.7(31.7-34.2)$ & \\
& & & \\
\end{tabular}




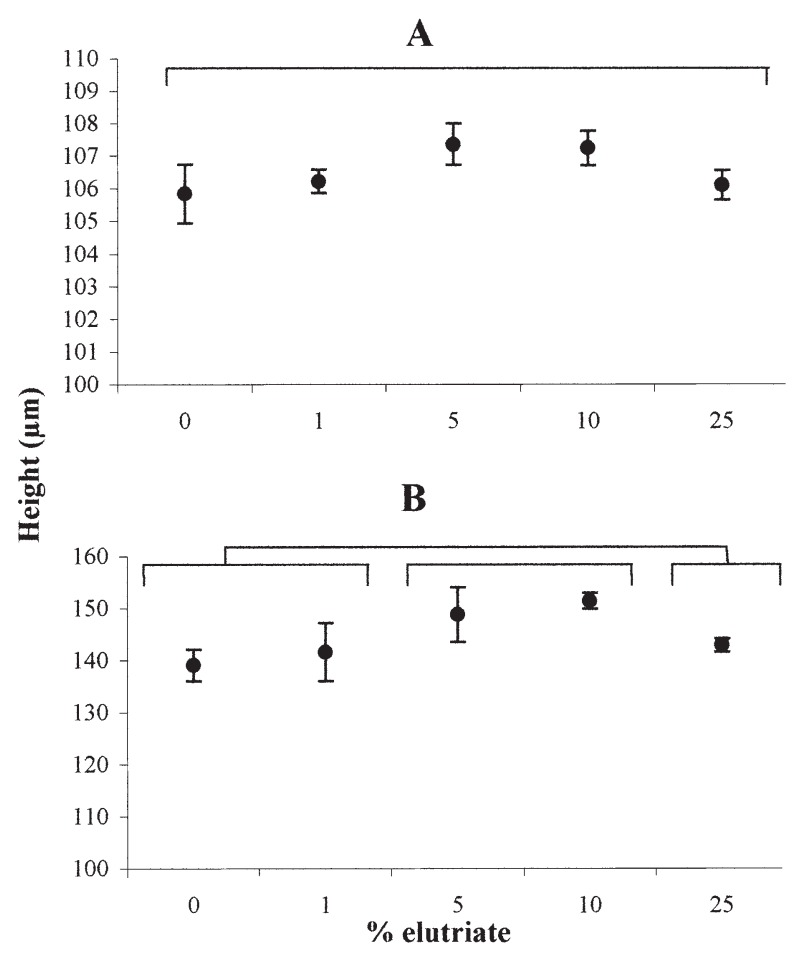

Fig. 1. Mytilus galloprovincialis. Height ( $\mu \mathrm{m} \pm \mathrm{SD}$ ) of larvae after exposure to a range of sediment elutriate percentages for $48 \mathrm{~h}$ (A) and $96 \mathrm{~h}$ (B). Values not significantly different from each other are grouped under a common overhead line (ANOVA, p < 0.05; Tukey's HSD test). Each mean corresponds to 3 replicates of ca. 120000 and 20000 larvae at 48 and $96 \mathrm{~h}$, respectively

$\mathrm{ml}^{-1}$ for $\mathrm{Cd}$. The assays were validated using certified sediment and mussel tissue samples (Table 1). The results are expressed as $\mathrm{mg} \mathrm{kg}^{-1}$ dry weight. The total bioaccumulation of metals $(\mathrm{Cd}, \mathrm{Cu}$ and $\mathrm{Zn})$ in the larvae was calculated by summing up the amounts in the soluble (S1) and insoluble (P1) fractions.
Assay of larval metallothionein: The MT assay was performed in the S2 fraction by differential pulse polarography. The thiol groups (SH) were determined using Brdicka reagent (Brdicka 1933) according to the method described by Thompson \& Cosson (1984). Measurements were performed at a constant temperature $\left(4^{\circ} \mathrm{C}\right)$ on a polarograph with a PAR Model 174 analyser, a PAR/EG\&G Model 303 electrode in SMDE mode and an RE0089 type X-Y recorder. The MT amounts measured were determined by a standard addition method using MT rabbit liver metallothionein standard (Sigma Chemical Co.) (no MT standard exists for mussels). The validity of this method has been confirmed by Olafson \& Olsson (1991). The results are expressed in $\mathrm{mg} \mathrm{kg}^{-1}$ dry weight.

Statistical analysis. For each series of results, the comparison of values was tested by Student's $t$-tests or 1-way ANOVA (Statistica software) after checking the homogeneity of variances (Cochran's test). Significant differences (at the 95\% level) were then determined by Tukey's HSD test. Linear regressions were performed and correlation coefficients $(\mathrm{r})$ determined using Excel software.

\section{RESULTS}

\section{Characterization of sediment, FSW and elutriate}

The water content in the sediment tested was $51 \%$. The organic matter decreased from $7.12 \%$ in raw sediment to $3.6 \%$ after the preparation of the elutriate, indicating that about $50 \%$ of the sediment organic matter had been remobilized as soluble compounds in the elutriate. $\mathrm{Cd}, \mathrm{Cu}$ and $\mathrm{Zn}$ concentrations (expressed in $\mu \mathrm{g} \mathrm{g}^{-1}$ dry weight) were $0.67,33$ and 218 , respectively, for the sediment, and $0.485 \mu \mathrm{g} \mathrm{Cd} \mathrm{l}^{-1}$ and $35 \mathrm{\mu g} \mathrm{Zn} \mathrm{l}^{-1}$ for the elutriate (Table 2) (the samples for Cu determination of the elutriate were lost). Thus, dilutions of the raw elutri-

Table 2. Mytilus galloprovincialis. Cadmium, copper and zinc concentrations in the sediment ( $\left.\mu g \mathrm{~g}^{-1} \mathrm{dry} w \mathrm{wt} \pm \mathrm{SD}\right)$, filtered seawater $\left(\mu \mathrm{g} \mathrm{l}^{-1}\right.$, control used in this study), and concentrations at various estuarine and marine locations

\begin{tabular}{|lcccc|}
\hline & Cadmium & Copper & Zinc & Source \\
\hline Sediment & $0.67(0.04)$ & $33(3)$ & $218(31)$ & This study \\
Filtered seawater (Arcachon) & 0.015 & 0.4 & 7 & This study \\
Raw elutriate & 0.485 & Lost & 35 & This study \\
Loire estuary water (mouth) & $0.37(0.05-1.43)$ & $1.72(0.6-2.3)$ & $4.2(0.7-10.6)$ & RNO (1984) \\
Loire estuary water (open sea) & $0.02(0.02-0.02)$ & $1.67(0.6-2.7)$ & $3.85(1.9-5.8)$ & RNO (1984) \\
Gironde estuary water (mouth) & $0.67(0.3-1.7)$ & $5.92(2-14)$ & $12(6-24)$ & RNO (1984) \\
Gironde estuary water (mouth) & 0.380 & $3.6(2.2-5)$ & $10(8-12)$ & Cossa \& Lassus (1989) \\
Gironde estuary water (open sea) & $0.25(0.20-0.30)$ & & & Boutier et al. (1989) \\
Atlantic Ocean water (surface) & $0.002-0.016$ & & & \\
\hline
\end{tabular}


A

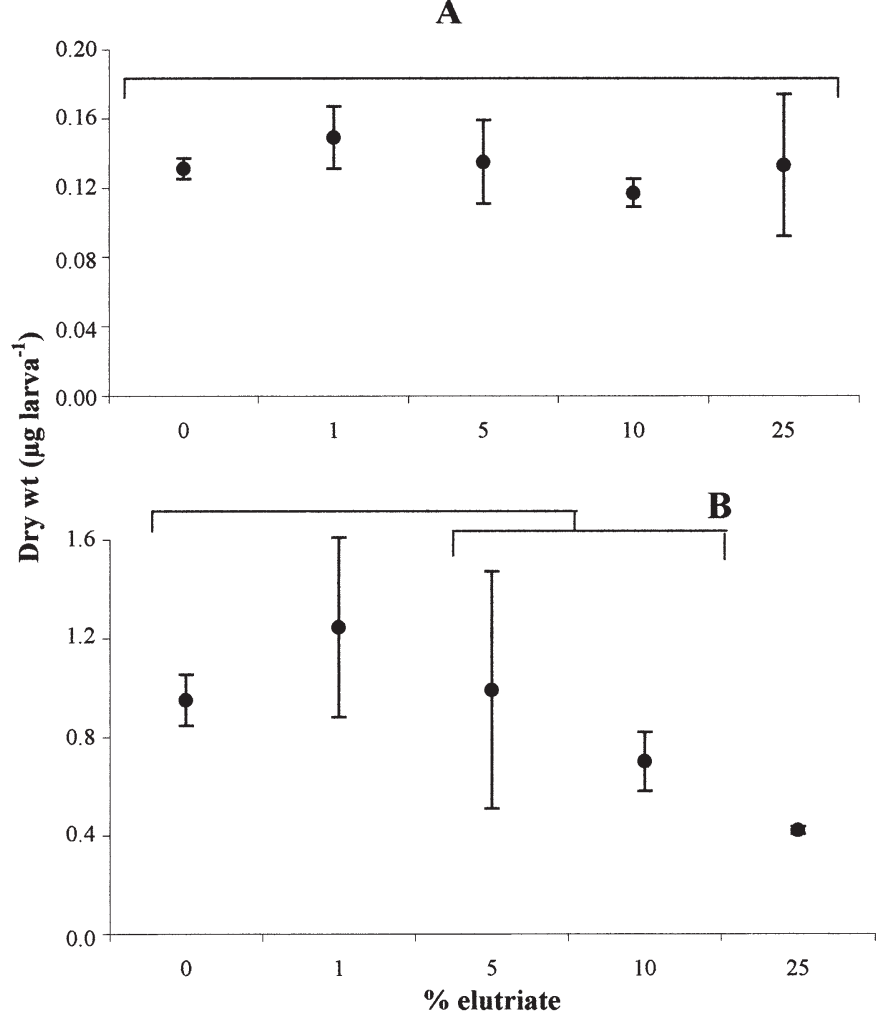

Fig. 2. Mytilus galloprovincialis. Dry weight $(\mu \mathrm{g} \pm \mathrm{SD})$ per larva after exposure to a range of sediment elutriate percentages for (A) $48 \mathrm{~h}$ and (B) $96 \mathrm{~h}$. Values not significantly different from each other are grouped under a common overhead line (ANOVA, $\mathrm{p}<0.05$; Tukey's HSD test). Each mean corresponds to 3 replicates of ca. 120000 and 20000 larvae at 48 and $96 \mathrm{~h}$, respectively

ate led to concentrations of $0.015,0.0197,0.0385,0.062$ and $0.14375 \mu \mathrm{g} \mathrm{Cd}^{-1}$ and 7, 7.28, 8.4, 9.8 and $14 \mu \mathrm{g} \mathrm{Zn}$ $\mathrm{l}^{-1}$ in $0,1,5,10$ and $25 \%$ elutriate, respectively.

\section{Larval rearing}

No larval deaths and abnormality occurred in the different rearing conditions. No significant differences in shell height were observed in any of the categories after $48 \mathrm{~h}$ (Fig. 1A). However, after $96 \mathrm{~h}$ (Fig. 1B), mean shell height had increased significantly (Tukey's HSD test, $\mathrm{p}=0.013$ ) from $138 \mu \mathrm{m}$ for controls to 149 and $151 \mu \mathrm{m}$ for larvae exposed to 5 and $10 \%$ elutriate, respectively. Mean shell height was only $141 \mu \mathrm{m}$ for larvae exposed to $25 \%$ elutriate, a value not significantly different from that of controls. The mean weight of 1 larva was calculated for the different categories. No significant differences were apparent in any of the categories at $48 \mathrm{~h}$ (Fig. 2A). At $96 \mathrm{~h}$, mean weight decreased significantly $(p<0.05)$ when the percentage of elutriate increased from 1 to $25 \%$ (Fig. 2B). The lowest value $(0.422 \mu \mathrm{g})$ was obtained with $25 \%$ elutriate. After $48 \mathrm{~h}$, the $\mathrm{CI}$ had not changed relative to the elutriate level (Fig. 3A). However, at 96 h (Fig. 3B) it decreased in larvae exposed to $5-25 \%$ elutriate, although the decrease only became significant $(\mathrm{p}<$ 0.05) upon exposure to $10 \%$ elutriate.

\section{Bioaccumulation of metals by larvae}

The concentration of total Cd (Fig. 4A) in veligers increased as a function of increasing elutriate percentage. The increase became significant at $48 \mathrm{~h}$ for concentrations above $5 \%$, with values ranging from $0.15 \mathrm{mg} \mathrm{kg}^{-1}$ (controls) to $0.45 \mathrm{mg} \mathrm{kg}^{-1}$ ( $25 \%$ elutriate). After $96 \mathrm{~h}$ exposure, the increase was significant ( $\mathrm{p}=$ 0.0001 ) for $10 \%$ elutriate and above, and Cd concentrations ranged from $0.06 \mathrm{mg} \mathrm{kg}^{-1}$ (controls) to $0.39 \mathrm{mg}$ $\mathrm{kg}^{-1}(25 \%$ elutriate).

The total concentration of $\mathrm{Cu}$ (Fig. 4B) also increased in larvae as a function of increasing elutriate percentage. This effect was noted with $5 \%$ elutriate and above after $48 \mathrm{~h}$ exposure and for $10 \%$ elutriate and above after $96 \mathrm{~h}$. At $48 \mathrm{~h}, \mathrm{Cu}$ concentrations ranged from $5.11 \mathrm{mg} \mathrm{kg}^{-1}$ (controls) to a maximum value of $11.6 \mathrm{mg}$

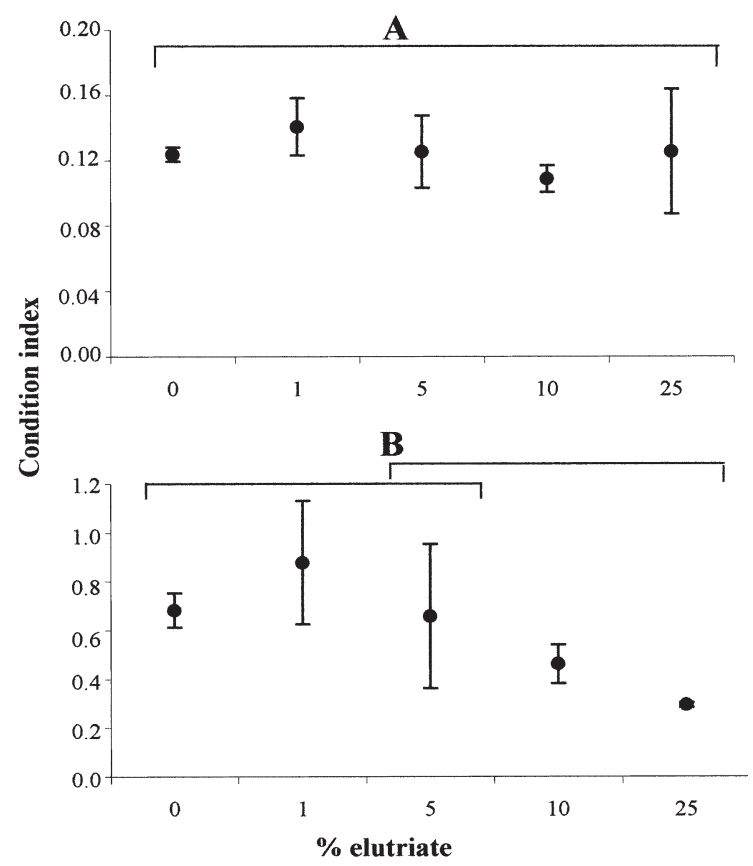

Fig. 3. Mytilus galloprovincialis. Condition index $( \pm \mathrm{SD})$ of larvae after exposure to a range of sediment elutriate percentages for (A) $48 \mathrm{~h}$ and (B) $96 \mathrm{~h}$. Values not significantly different from each other are grouped under a common overhead line (ANOVA, $\mathrm{p}<0.05$; Tukey's HSD test). Each mean corresponds to 3 replicates of ca. 120000 and 20000 larvae at 48 and $96 \mathrm{~h}$, respectively 

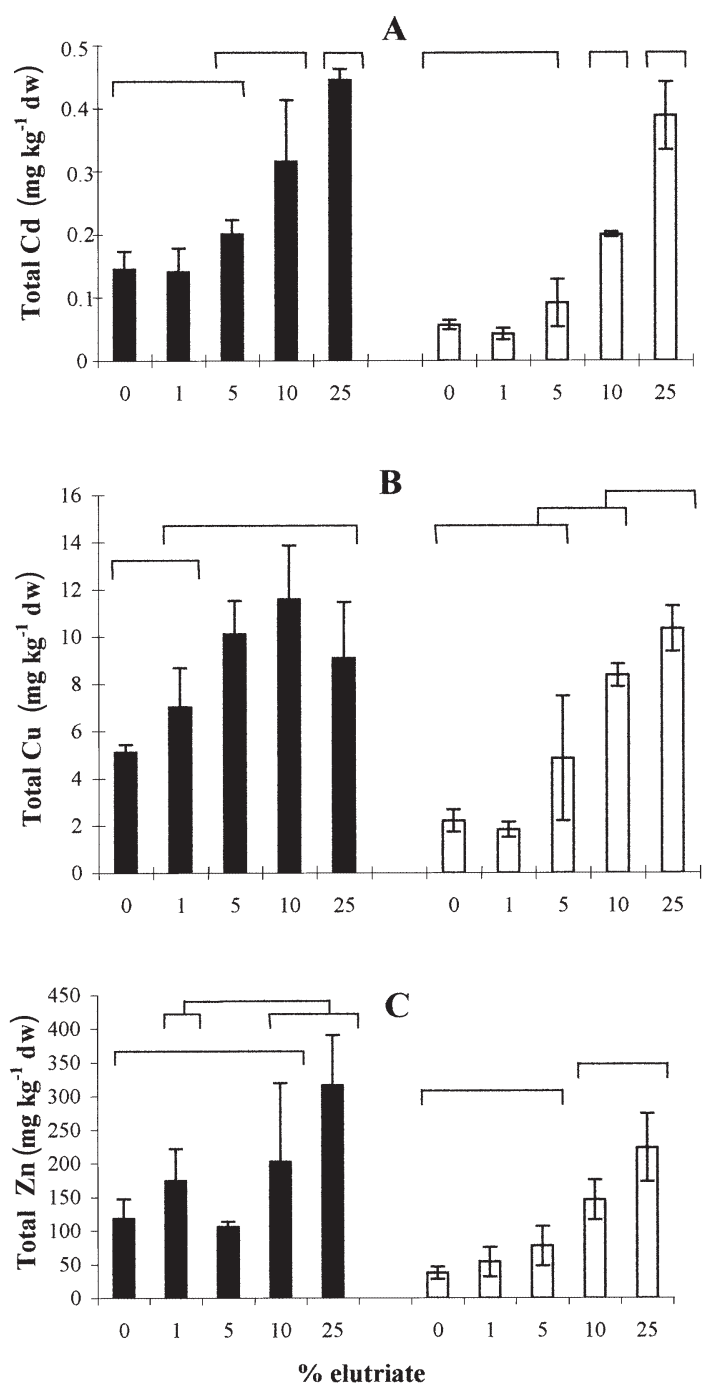

Fig. 4. Mytilus galloprovincialis. Total metal (soluble + insoluble; mean $\pm \mathrm{SD}$ ) concentrations (A: $\mathrm{Cd}_{i} \mathrm{~B}: \mathrm{Cu}_{i} \mathrm{C}$ : $\left.\mathrm{Zn}\right)$ in larvae after exposure to a range of sediment elutriate percentages for $48 \mathrm{~h}$ (solid bars) and $96 \mathrm{~h}$ (open bars). Values not significantly different from each other are grouped under a common overhead line (ANOVA, $\mathrm{p}<0.05$; Tukey's HSD test). Each mean corresponds to 3 replicates of ca. 120000 and 20000 larvae at 48 and $96 \mathrm{~h}$, respectively

$\mathrm{kg}^{-1}(10 \%$ elutriate), and after $96 \mathrm{~h}, \mathrm{Cu}$ concentrations ranged from $2.21 \mathrm{mg} \mathrm{kg}^{-1}$ for controls to $10.35 \mathrm{mg} \mathrm{kg}^{-1}$ for individuals exposed to $25 \%$ elutriate.

For Zn (Fig. 4C), a significant increase after $48 \mathrm{~h}$ was noted only at the highest elutriate percentage tested, with values of $119 \mathrm{mg} \mathrm{kg}^{-1}$ in controls and $316 \mathrm{mg} \mathrm{kg}^{-1}$ with $25 \%$ elutriate. After $96 \mathrm{~h}$, the increase was significant for $10 \%$ elutriate and above, with values of $38 \mathrm{mg} \mathrm{kg}^{-1}$ for controls and $224 \mathrm{mg}$ $\mathrm{kg}^{-1}$ with $25 \%$ elutriate.
For each percentage of elutriate tested, the metal concentration was generally lower in specimens exposed for $96 \mathrm{~h}$ than in those exposed for $48 \mathrm{~h}$ (except in the case of $\mathrm{Cu}$ with larvae exposed to $25 \%$ elutriate). However, for all 3 metals studied, these differences were significant $(0.0009<\mathrm{p}<0.0392)$ only in control and in larvae exposed to 1 and $5 \%$ elutriates. For each metal and condition, the total metal quantities $(\mathrm{S} 1+\mathrm{P} 1)$ per individual were always greater $(0.0001<\mathrm{p}<0.0255)$ after $96 \mathrm{~h}$ exposure (not shown), indicating that despite a lowering of concentrations, metals were incorporated in larvae throughout the exposure.
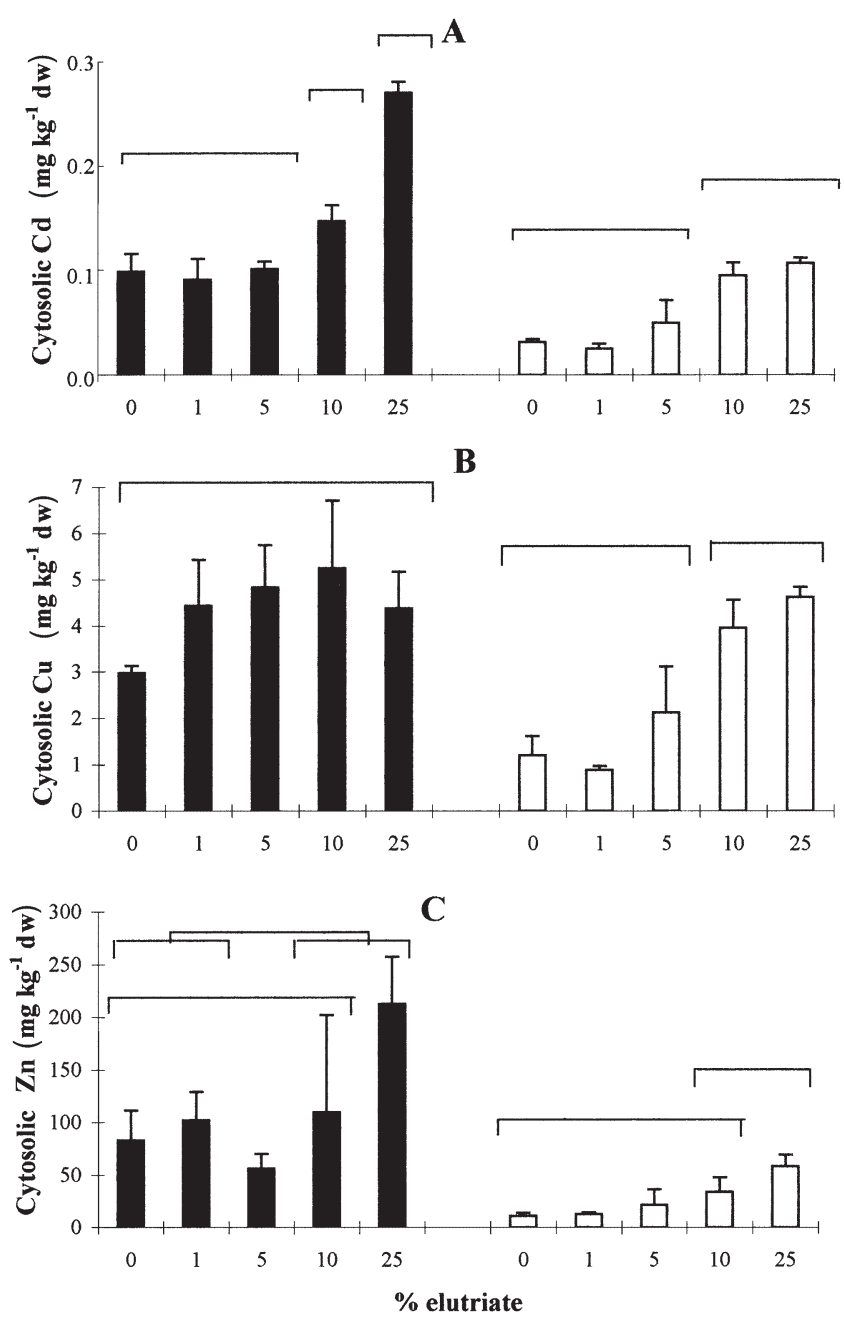

Fig. 5. Mytilus galloprovincialis. Cytosolic (S1) metal (mean \pm $\mathrm{SD})$ concentrations (A: $\mathrm{Cd}$; $\mathrm{B}: \mathrm{Cu}_{i} \mathrm{C}: \mathrm{Zn}$ ) in larvae after exposure to a range of sediment elutriate percentages for $48 \mathrm{~h}$ (solid bars) and $96 \mathrm{~h}$ (open bars). Values not significantly different from each other are grouped under a common overhead line (ANOVA, p < 0.05; Tukey's HSD test). Each mean corresponding to 3 replicates of ca. 120000 and 20000 larvae at 48 and $96 \mathrm{~h}$, respectively 
For the cytosolic fraction (Fig. 5), metal concentrations generally increased significantly with increasing degree of exposure (percentage of elutriate). The concentrations of cytosolic Cd (Fig. 5A) increased significantly $(p<0.05)$ after $48 \mathrm{~h}$ at the highest percentages of elutriate tested (10 and $25 \%$ ), with values of $0.10 \mathrm{mg}$ $\mathrm{kg}^{-1}$ for controls and $0.27 \mathrm{mg} \mathrm{kg}^{-1}$ with $25 \%$ elutriate. At $96 \mathrm{~h}$, this rise was significant for $10 \%$ elutriate and above, with values of $0.03 \mathrm{mg} \mathrm{kg}^{-1}$ for controls and a maximum value of $0.11 \mathrm{mg} \mathrm{kg}^{-1}$ with $25 \%$ elutriate.

Individuals exposed to elutriate for $48 \mathrm{~h}$ (Fig. 5B) had $\mathrm{Cu}$ concentrations greater than those of controls, although the difference was not significant. Cu concentrations varied from $2.99 \mathrm{mg} \mathrm{kg}^{-1}$ in controls to $5.24 \mathrm{mg} \mathrm{kg}^{-1}$ with $10 \%$ elutriate. At $96 \mathrm{~h}$, the increase was significant $(\mathrm{p}=0.0001)$ for $10 \%$ and above, and cytosolic $\mathrm{Cu}$ concentrations ranged between $0.88 \mathrm{mg}$ $\mathrm{kg}^{-1}$ with $1 \%$ elutriate and $4.63 \mathrm{mg} \mathrm{kg}^{-1}$ with $25 \%$.

Cytosolic Zn (Fig. 5C) increased significantly after $48 \mathrm{~h}$ exposure to $25 \%$ elutriate compared to individuals exposed to $5 \%$ elutriate, with values between $56 \mathrm{mg} \mathrm{kg}^{-1}$ (5\% elutriate) and $212 \mathrm{mg} \mathrm{kg}^{-1}$ (25\% elutriate). After $96 \mathrm{~h}$, the increase was significant for $10 \%$ elutriate and above, with values of $11 \mathrm{mg} \mathrm{kg}^{-1}$ in controls and $58 \mathrm{mg} \mathrm{kg}^{-1}$ with $25 \%$ elutriate.

Specimens exposed for $96 \mathrm{~h}$ exhibited lower metal concentrations than those exposed for $48 \mathrm{~h}$, except in the case of $\mathrm{Cu}$ when specimens were exposed to $25 \%$ elutriate. These differences were generally significant except for $\mathrm{Cu}$ and $\mathrm{Zn}$ in specimens exposed to $10 \%$ elutriate $(p=0.3412$ and $p=0.35$, respectively). As mentioned above for total metal quantities (S1 + P1), the quantities of cytosolic metals were significantly $(0.0001<\mathrm{p}<$ $0.0414)$ greater in individuals exposed for the longer period, except for Cd with $25 \%$ elutriate $(p=0.2051)$ and Zn for all exposure levels ( $p>0.0767$ ) (not shown).

The distribution of $\mathrm{Cd}$ among cytosolic and insoluble tissue fractions remained the same, regardless of the incorporation level after $48 \mathrm{~h}$ (Fig. 6A). However, at $96 \mathrm{~h}$, $\mathrm{Cd}$ became predominant in the insoluble fraction when incorporation increased (Fig. 6B), reaching $75 \%$ of total $\mathrm{Cd}$ in larvae exposed to $25 \%$ elutriate. Cu was distributed equally between the 2 tissue fractions and for both time periods (data not shown). For $48 \mathrm{~h}$ old larvae, cytosolic $\mathrm{Zn}$ increased as a function of the degree of contamination, reaching 60 to $70 \%$ in the most contaminated individuals (Fig. 7A). After 96 h, Zn was found mainly in the insoluble fraction, with a maximum value of $80 \%$ for individuals exposed to $25 \%$ elutriate (Fig. 7B).

\section{Metallothionein}

MT concentrations are shown in Fig. 8. During the first $48 \mathrm{~h}$ of exposure, MT concentration was not signif- icantly affected by exposure of larvae to different doses of elutriates in their medium $(p=0.932)$. In larvae exposed for $96 \mathrm{~h}$, a significant $(\mathrm{p}=0.0008)$ increase in MT concentration was observed in specimens exposed to doses of $10 \%$ elutriate and above. As shown previously for the metals, MT concentrations were significantly lower $(0.0001<\mathrm{p}<0.0458)$ after $96 \mathrm{~h}$ exposure than after $48 \mathrm{~h}$, except for larvae exposed to the highest dose of elutriate $(p=0.9908)$. In contrast to the results for the MT concentrations, at $96 \mathrm{~h}$ the amount of MT did not increase with increasing metal accumulation (not shown): the amount of MT was significantly $(p=0.001)$ higher in larvae exposed to any elutiate concentration ( 0.58 to $0.69 \mathrm{ng}$ larvae ${ }^{-1}$ ) than in controls (0.42 ng), but was similar in all specimens exposed to the various concentrations ( 1 to $25 \%$ ) of elutriates.

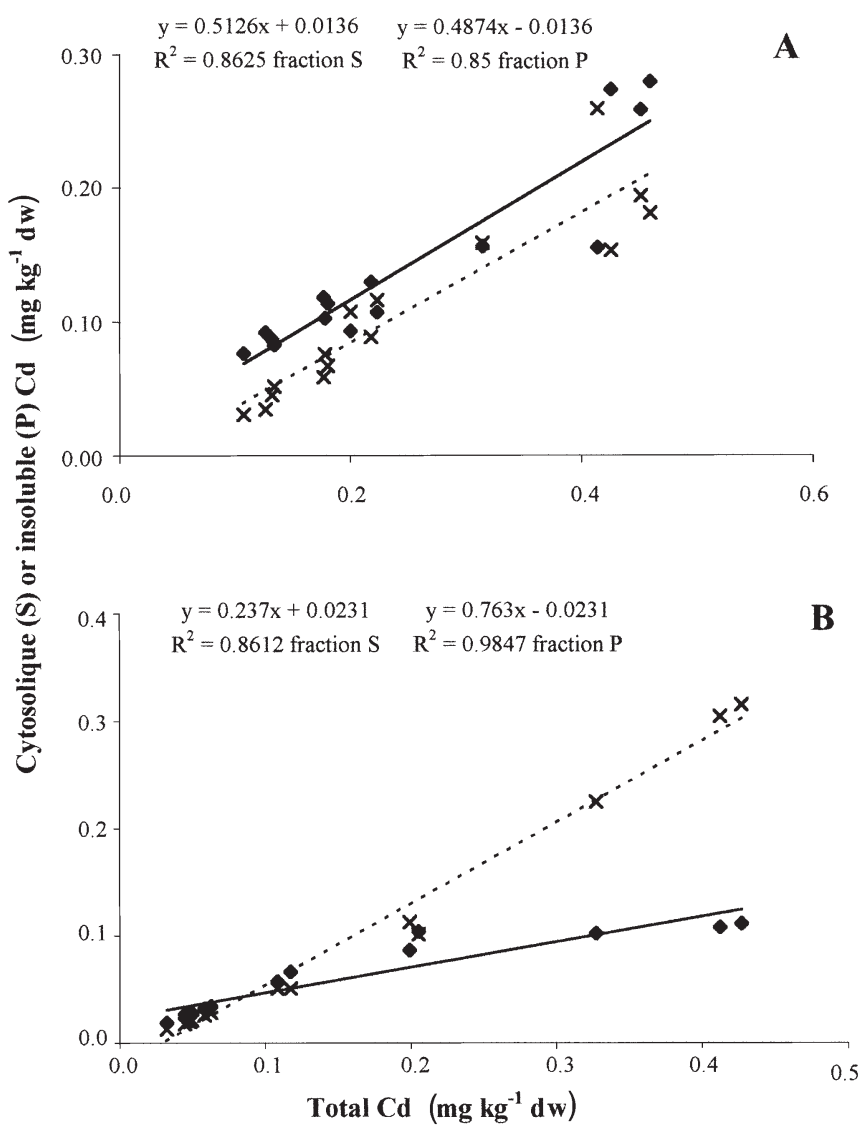

Fig. 6. Mytilus galloprovincialis. Relationships between total and cytosolic (solid lines) or insoluble (dotted lines) $\mathrm{Cd}$ in larvae after exposure to a range of sediment elutriate percentages for (A) $48 \mathrm{~h}$ or (B) $96 \mathrm{~h}$. Equations and correlation coefficients were determined for each fraction. Each replicate contained ca. 120000 and 20000 larvae at 48 and $96 \mathrm{~h}$, respectively 


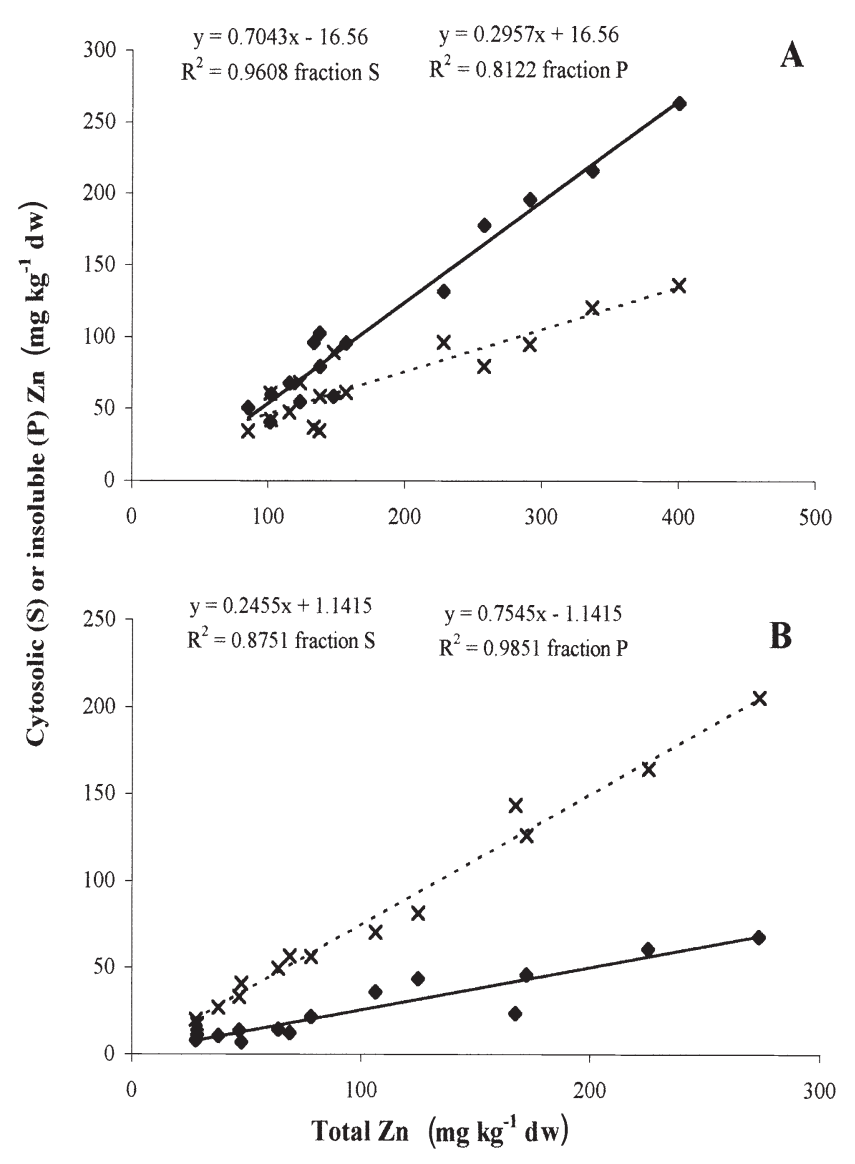

Fig. 7. Mytilus galloprovincialis. Relationships between total and cytosolic (solid lines) or insoluble (dotted lines) $\mathrm{Zn}$ in larvae after exposure to a range of sediment elutriate percentages for (A) $48 \mathrm{~h}$ or (B) $96 \mathrm{~h}$. Equations and correlations coefficient were determined for each fraction. Each replicate contained ca. 120000 and 20000 larvae at 48 and 96 h, respectively

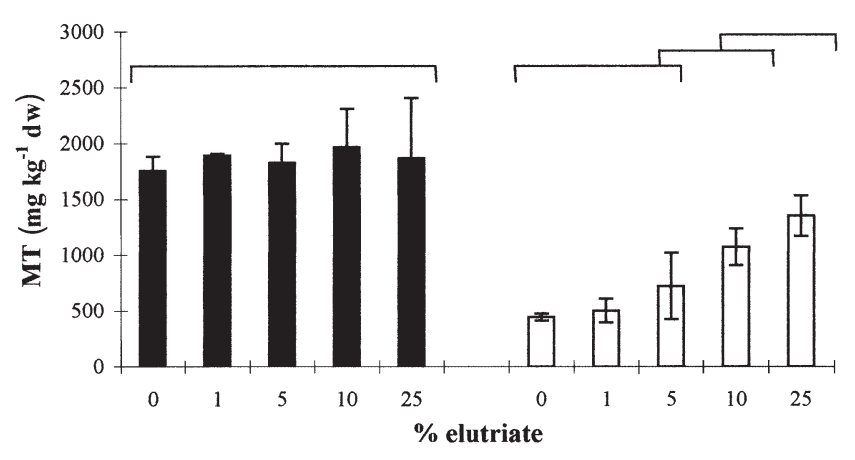

Fig. 8. Mytilus galloprovincialis. Metallothionein concentrations (means $\pm \mathrm{SD}$ ) in larvae after exposure to a range of sediment elutriate percentages for $48 \mathrm{~h}$ (solid bars) or $96 \mathrm{~h}$ (open bars). Values not significantly different from each other are grouped under a common overhead line (ANOVA, $\mathrm{p}<0.05$; Tukey's HSD test). Each mean corresponds to 3 replicates of ca. 120000 and 20000 larvae at 48 and 96 h, respectively
Table 3. Mytilus galloprovincialis. Equations showing relationship between cytosolic $\mathrm{Cd}, \mathrm{Cu}, \mathrm{Zn}$ or $\mathrm{Cd}+\mathrm{Cu}+\mathrm{Zn}$ and metallothionein in larvae after $96 \mathrm{~h}$ exposure to a range of sediment elutriate concentrations. $\mathrm{n}=$ number of samples $(3$ for each elutriate concentration tested) $r^{2}=$ correlation coefficient; ${ }^{* *}$ relationship significantly correlated at $99 \%$

\begin{tabular}{|lccc|}
\hline Metal & Equation & $\mathrm{n}$ & $\mathrm{r}^{2}$ \\
\hline $\mathrm{Cd}$ & $y=10166 x+205.5$ & 15 & $0.888^{* *}$ \\
$\mathrm{Cu}$ & $y=228.53 x+240.03$ & 15 & $0.8829^{* *}$ \\
$\mathrm{Zn}$ & $y=16.043 x+380.01$ & 15 & $0.7168^{* *}$ \\
$\mathrm{Cd}+\mathrm{Cu}+\mathrm{Zn}$ & $y=1015.9 x+341.36$ & 15 & $0.7458^{* *}$ \\
\hline
\end{tabular}

\section{Relationships between metals and metallothionein}

As all 3 elements studied ( $\mathrm{Cd}, \mathrm{Cu}$ and $\mathrm{Zn}$ ) bind to $\mathrm{MT}$ and might therefore contribute concomitantly to MT induction, the relationship between MT and metal levels was examined taking into account the metals individually or combined ( $\mathrm{mg}$ at. $\mathrm{kg}^{-1}$ dry wt)

No significant correlation was observed between concentration of $\mathrm{MT}$ and that of cytosolic $\mathrm{Cd}, \mathrm{Cu}, \mathrm{Zn}$ or a mixture of these 3 metals during the first period of exposure (48 $h_{i}$ results not shown). In larvae exposed for $96 \mathrm{~h}$, strongly significant positive relationships were always observed (Table 3), whether metals were considered individually or combined.

\section{DISCUSSION}

The sediment from the Gironde estuary tested in the present study was a fine mud with relatively high levels of organic matter. Desorption tests have shown that 15,35 and $55 \%$ of sediment-bound $\mathrm{Cd}$ were extractable at pH 7.1, 5.5 and 4.1, respectively (Geffard 2001). Similar results were obtained in sediments collected previously in the same estuary (Amiard-Triquet et al. 1998a). Morever, bioassays carried out with the sediment used in the present study showed that the main metal contaminants $(\mathrm{Cd}, \mathrm{Cu}$ and $\mathrm{Zn})$ were bioavailable, as demonstrated by the large number of larval abnormalities found at high concentrations of elutriate (100\%: Geffard 2001). The seawater used in the present study was obtained from the Bay of Arcachon, which is extensively used for oyster farming based on Pacific oysters Crassostrea gigas and was thus assumed to have good 'biological quality' (His et al. 1999). (For instance, as shown in Table 2, metal concentrations were consistently lower in the Bay of Arcachon than in the Loire and Gironde estuaries.) From the $\mathrm{Cd}$ and $\mathrm{Zn}$ concentrations in the raw elutriate and seawater, and the percentages of this elutriate tested in the bioassays herein, it is estimated that larvae were 
exposed to doses varying from 0.019 to $0.122 \mathrm{ug} \mathrm{Cd}^{-1}$ and from 7.3 to $14 \mu \mathrm{gn} \mathrm{l}^{-1}$, concentrations representative of those found in the Gironde estuary waters (Table 2). According to Boutier et al. (1989), seawater must be considered contaminated if $\mathrm{Cd}$ concentrations exceed $0.03 \mu \mathrm{g} \mathrm{l}^{-1}$. Nevertheless, the concentrations of both $\mathrm{Cd}$ and $\mathrm{Zn}$ were lower than those affecting embryogenesis in Mytilus galloprovincialis $\left(\mathrm{EC}_{50}\right.$ of $4000 \mathrm{~g} \mathrm{l}^{-1}$ for $\mathrm{Cd}$ and $145 \mathrm{\mu g} \mathrm{l}^{-1}$ for $\mathrm{Zn}_{\text {; }}$ see review by His et al. 1999). The EC50 for Cu were comparatively very low, from 3.2 to $10 \mathrm{\mu g} \mathrm{l}^{-1}$ (His et al. 1999), that is to say, in the same order of magnitude as $\mathrm{Cu}$ concentrations at the mouth of the Gironde (Table 2). The speciation of these metals in natural waters of the Gironde estuary as well as in the elutriate, and thus their potential toxicity, presumably differed from those of the metal salts used in other bioassays. It has been shown that a significant fraction of the organic matter initially present in the sediment was indeed remobilized concomitantly with metals during elutriation.

No mortality occurred during the experiments and no abnormal larvae were observed. No significant differences were registered in regard to shell height, weight or the condition index of larvae exposed to sediment elutriates for $48 \mathrm{~h}$. At $96 \mathrm{~h}$, mean shell height was slightly greater in 5 and $10 \%$ elutriates, either as a result of hormesis phenomena (Stebbing 1982) or the additional supply of small amounts of essential elements or soluble organic matter which may have enhanced larval growth. However, at $25 \%$ elutriate, larval height was no longer different from that of controls. The $96 \mathrm{~h}$ old larvae reared at elutriate concentrations higher than $10 \%$ had a lower weight than controls, with a correspondingly lower condition index (CI), which may thus represent an early indicator of stress. Determination of the CI in veligers exposed to micropollutants may therefore constitute a more sensitive toxicity endpoint than larval growth based on the determination of height, which is the criterion commonly used to assess sublethal toxicity (His et al. 1999).

Metal levels in the whole larvae as well as in their cytosol (particularly Cd), increased with increasing degree of contamination in the experimental medium. The potential bioavailability of sediment-bound metals was also observed by Fichet et al. (1998) in the larvae of several invertebrate species. At similar doses of contaminants in the experimental medium, metal levels in larvae were lower at $96 \mathrm{~h}$ than at $48 \mathrm{~h}$. Such a phenomenon, termed 'biological dilution', corresponds to a tissue growth which is faster than metal incorporation, leading to a decrease in the concentration. Similar negative relationships between metal concentration and weight (and/or age and/or size) have been observed in adults from different species (Langston et al. 1998), including mussels and oysters (Amiard et al.
1986, Amiard \& Berthet 1996) and particularly the spat of clams Ruditapes philippinarum (Amiard et al. 1991a) and oysters (Amiard et al. 1994). Moreover, in the bivalve Isognomon californicum, Ringwood (1991) observed a higher accumulation rate of $\mathrm{Cd}$ during embryogenesis than in veligers and pediveligers, with highest concentrations in embryos. As for metals, MT concentrations were lower in $96 \mathrm{~h}$ old larvae. The general growth of larval tissues was more important that the induction rate of this particular protein. Similarly, negative relationships between tissue weight and MT concentrations have been observed previously in adults belonging to different bivalve species, such as Crassostrea gigas (Mouneyrac et al. 1998) or Macoma balthica (Amiard-Triquet et al. 1998b).

No MT induction was observed during embryogenesis $(48 \mathrm{~h})$ in larvae exposed to different doses of elutriates. This may be due to the fact that little uptake occurred in the soluble fraction, except at the highest doses of Cd and Zn. Pavicic et al. (1994) observed MT induction during embryogenesis, but in specimens exposed to high doses of $\mathrm{Cd}\left(2.75 \mathrm{mg} \mathrm{l}^{-1}\right)$. At the lower doses tested in our study, the amount of MT in oocytes (termed 'maternal MT' by Roesijadi et al. 1996 in Crassostrea virginica) could be sufficient to regulate the essential needs of the larvae, particularly with respect to $\mathrm{Zn}$, as well as to handle excessive amounts of $\mathrm{Cd}$. In addition, in regard to MT concentrations, the important decrease in $96 \mathrm{~h}$ old specimens compared to $48 \mathrm{~h}$ old is striking. It must be noted that the tissue distribution of $\mathrm{Cd}$ and $\mathrm{Zn}$ is strongly modified during this period of the life cycle, with the highest concentrations of soluble metals and the highest MT concentrations being recorded in $48 \mathrm{~h}$ old specimens. If larvae have to cope with metals after this period of embryogenesis, their native MT is no longer sufficient to detoxify additional metals, particularly $\mathrm{Cd}$ and $\mathrm{Cu}$, which have the greatest affinity for this protein (Viarengo \& Nott 1993). Therefore, between the age of 2 and $4 \mathrm{~d}, \mathrm{MT}$ induction enables the larvae to detoxify $\mathrm{Cd}$ and other essential elements present in excessive amounts. Indeed, in the $96 \mathrm{~h}$ old larvae, the MT concentration increase paralleled increasing doses of sediment elutriate in the medium. However, in these $96 \mathrm{~h}$ old larvae, MT amounts were higher in exposed larvae than in controls, but no significant differences were revealed between elutriate treatments ( 1 to $25 \%$ elutriate). The similarity of MT amounts in $96 \mathrm{~h}$ old larvae exposed to a range of contaminant doses as well as their relatively poor physiological state (CIs lower than controls) could evoke a situation which has previously been termed 'spillover' (Brown \& Parsons 1978). This phenomenon has been described in field experiments with the freshwater bivalve Corbicula fluminea translocated along a polymetallic $(\mathrm{Cd}, \mathrm{Zn})$ pollution gradient: at the most 
polluted station, where mortality occurred, MT levels did not increase despite a very important metal accumulation, whereas at lesser impacted sites, positive correlations were registered between metal and MT levels (Baudrimont et al. 1999).

\section{CONCLUSIONS}

No assessment of potential noxious effects on living organisms can be derived from chemical analysis carried out to determine the pollution of sediments. The complex actions and the bioavailability of contaminants depend on their speciation (Kersten \& Förstner 1989, Luoma 1995), and accurate assessment requires bioassays (Chapman \& Long 1983, Burton 1992, Miller et al. 2000).

By determining veliger contamination and MT induction, bioassays with D-stage larva of Mytilus galloprovincialis in the present study showed that contaminated sediment from the Gironde estuary releases metal micropollutants into the water column. As indicated by Bayne (1985): 'the molecules that probably offer the greatest potential for monitoring of biological effects ... are enzymes, and the functional proteins such as metallothioneins'. Bivalve embryos and larvae are the marine organisms of choice for bioassays. In a review of the literature, His et al. (1999) classified the various larval stages by their sensitivity to micropollutants as: growth > embryogenesis > D-stage larva > umboned larva $>$ pediveliger. In agreement with the conclusions of Bayne (1985) and Pavicic et al. (1994), the present study confirms the greater sensitivity of MT induction compared to larval growth (based on larvae height) and even the $\mathrm{CI}$ in veligers.

With regard to regulations for the protection of the coastal environment, the assessment of sediment quality, which is essential to any management activity, is mainly based today on tests with various marine organisms. The 'sediment quality triad' of Chapman et al. (1987) is one of the most sophisticated methods for this purpose. If measures are to be taken to protect the economically important aquaculture sector, it is necessary to use the most sensitive instruments available, such as an early indicator of stress. This is particularly true for enclosed bodies of water in which the natural reproduction of bivalves constitutes the basis for an entire area of the economy. A striking example of this is tributyltin (TBT) in antifouling paints, which caused reproduction failure in Crassostrea gigas over a period of about $5 \mathrm{yr}$ and almost led to the disappearance of oyster culture in the Bay of Arcachon (His 1996).

In closed bays with extensive reproduction, it is possible to monitor cohorts of larvae in the natural environment, both for their growth and biochemical com- position (His \& Maurer 1988). However, except in special cases, it is difficult to identify the possible causes of reproductive failure (i.e. poor larval growth, with important size differences within the same cohort) that may result from various environmental factors and/or 1 or more micropollutants in the environment (e.g. His et al. 1999). As it is possible to isolate bivalve larvae in sufficient numbers for biochemical analysis, it should be easy to identify unfavourable causes due to metal micropollutant effects by measuring MT induction in veligers.

\section{LITERATURE CITED}

Amiard JC, Berthet B (1996) Fluctuations of cadmium, copper, lead and zinc concentrations in field populations of the Pacific oyster Crassostrea gigas in the bay of Bourgneuf (Atlantic coast, France). Ann Inst Océanogr 72:195-207

Amiard JC, Cosson RP (1997) Les métallothionéines. In: Lagadic L, Caquet T, Amiard JC, Ramade F (eds) Biomarqueurs en écotoxicologie-aspects fondamentaux. Masson, Paris, p 53-66

Amiard JC, Amiard-Triquet C, Berthet B, Métayer C (1986) Contributions to the ecotoxicological study of cadmium, lead, copper and zinc in the mussel Mytilus edulis. I. Field study. Mar Biol 90:425-431

Amiard JC, Pineau A, Boiteau HL, Métayer C, Amiard-Triquet C (1987) Application de la spectrométrie d'absorption atomique Zeeman aux dosages de huit éléments traces ( $\mathrm{Ag}, \mathrm{Cd}, \mathrm{Cr}, \mathrm{Cu}, \mathrm{Mn}, \mathrm{Ni}, \mathrm{Pb}$ et $\mathrm{Se}$ ) dans les matrices biologiques solides. Water Res 21:693-697

Amiard JC, Métayer C, Baud JP, Ribeyre F (1991a) Influence de divers facteurs écologiques sur la bioaccumulation d'éléments métalliques ( $\mathrm{Cd}, \mathrm{Cu}, \mathrm{Zn}, \mathrm{Pb})$ chez les jeunes palourdes (Ruditapes philippinarum) au cours du prégrossissement en nourricerie. Rev Sci Eau 4: 441-452

Amiard JC, Queguiner F, Camus Y (1991b) Variations spatiales des concentrations métalliques $(\mathrm{Cd}, \mathrm{Cu}, \mathrm{Pb})$ des eaux de la mer d'Iroise. Oceanol Acta 14:141-150

Amiard JC, Métayer C, Baud JP, Ribeyre F (1994) Influence of some ecological and biological factors on metal bioaccumulation in young oysters (Crassostrea gigas Thunberg) during their spat rearing. Water Res 28:219-231

Amiard-Triquet C, Altmann S, Amiard JC, Ballan-Dufrançais $\mathrm{C}$ and 11 others (1998a) Fate and effects of micropollutants in the Gironde Estuary, France: a multidisciplinary approach. Hydrobiologia 373/374:259-279

Amiard-Triquet C, Rainglet F, Larroux C, Régoli F, Hummel H (1998b) Metallothioneins in arctic bivalves. Ecotoxicol Environ Saf 41:96-102

Baudrimont $\mathrm{M}$, Andrès $\mathrm{S}$, Metivaud $\mathrm{J}$, Lafaquellerie $\mathrm{Y}$, Ribeyre F, Maillet N, Latouche C, Boudou A (1999) Field transplantation of the freshwater bivalve Corbicula fluminea along a polymetallic contamination gradient (river Lot, France): II. Metallothionein response to metal exposure. Environ Toxicol Chem 18:2472-2477

Bayne BL (1985) Ecological consequences of stress. 4. Biochemical measurements. In: Bayne BL, Brown DA, Burns $\mathrm{K}$, Dixon DR, Ivanovici A, Livingstone DR, Lowe DM, Moore MN, Stebbing ARD, Widdows J (eds) The effects of stress and pollution on marine animals. Praeger Publishers, New York, p 81-140 
Berman SS, Sturgeon RE, Desaulniers JAH, Mykytiuk AP (1983) Preparation of the seawater reference material for trace metals, NASS-1. Mar Pollut Bull 14:69-73

Boiteau HL, Metayer C (1978) Microdosage du plomb, du cadmium, du zinc et de l'étain dans des milieux biologiques par spectrométrie d'absorption atomique après minéralisation et extraction. Analusis 6:350-358

Boutier B, Chiffoleau JF, Jouanneau JM, Latouche C, Philipps I (1989) La contamination de la Gironde par le cadmium: origine, extension, importance. Institut Francais pour l'Exploration de la Mer, Plouzané (Rapp Sci Tech 14)

Brdicka A (1933) Polarographic studies with the dropping mercury method. A new test for proteins in the presence of cobalt salts in ammoniacal solution of ammonium chloride. Collect Czech Chem Commun 5:112-128

Brown DA, Parsons TR (1978) Relationship between cytoplasmic distribution of mercury and toxic effects to zooplankton and chum salmon (Oncorhynchus keta) exposed to mercury in a controlled ecosystem. J Fish Res Board Can 35:880-884

Budzinski H, Jones I, Bellocq J, Piérard C, Garrigues P (1997) Evaluation of sediment contamination by polycyclic aromatic hydrocarbons in the Gironde estuary. Mar Chem 58: 85-97

Burton GA Jr (1992) Sediment toxicity assessment. Lewis Publishers, London

Cardwell RD, Woelke CE, Carr MI, Sanborn EW (1976) Sediment and elutriate toxicity to oyster larvae. In: Krenkel PA, Harrisson J, Burdick JC (eds) Proceedings of the special conference on dredging and its environmental effects, 3rd edn. American Society of Civil Engineers, New York, p 684-718

Chapman PM, Long ER (1983) The use of bioassays as part of a comprehensive approach to marine pollution assessment. Mar Pollut Bull 14:81-84

Chapman PM, Dexter RN, Long ER (1987) Synoptic measures of sediment contamination, toxicity and infaunal community composition (the sediment quality triad) in San Francisco Bay. Mar Ecol Prog Ser 37:75-96

Charlot G (1966) Les méthodes de la chimie analytique. Analyse quantitative minérale. Masson, Paris

Charlou JL, Joanny M (1983) Dosage du mercure et d'autres métaux $(\mathrm{Pb}, \mathrm{Zn}, \mathrm{Cu}, \mathrm{Cd}, \mathrm{Co}, \mathrm{Ni}, \mathrm{Cr}, \mathrm{Mn})$ dans les sédiments marins par adsorption atomique. In: CNEXO (ed) Manuel des analyses chimiques en milieu marin, Centre National pour lesqloitation des Océans, Brest, p 285-295

Cossa D, Lassus P (1989) Le cadmium en milieu marin, biogéochimie et écotoxicologie. Institut Français pour l'Exploration de la Mer, Plouzané (Rapp Sci Tech No. 16)

Cosson RP (2000) Bivalve metallothioneins as a biomarker of aquatic ecosystem pollution by trace metals: limits and perspectives. Cell Mol Biol (Oxf) 46: 295-309

Cosson RP, Amiard JC (2000) Use of metallothioneins as biomarkers of exposure to metals. In: Lagadic L, Caquet $\mathrm{T}$, Amiard JC, Ramade F (eds) Use of biomarkers for environmental quality assessment. Science Publishers, Plymouth, p 79-111

Fichet D, Radenac G, Miramand P (1998) Experimental studies of impacts of harbour sediments resuspension to marine invertebrates larvae: bioavailability of $\mathrm{Cd}, \mathrm{Cu}, \mathrm{Pb}$ and Zn and toxicity. Mar Pollut Bull 36: 509-518

Geffard A (2001) Réponses du biota à la contamination polymétallique d'un milieu estuarien, la Gironde, Fr: exposition, imprégnation, induction d'une protéine de détoxication, la métallothionéine, impact au niveau individuel et populationnel. Thèse de doctorat, Université de Nantes
George SG, Olsson PE (1994) Metallothioneins as indicators of trace metal pollution. In: Kramer KJM (ed) Biomonitoring of coastal waters and estuaries. CRC Press, Boca Raton, p 151-178

Helm MM, Millican PF (1977) Experiments in the hatchery rearing of Pacific oyster larvae (Crassostrea gigas Thunberg). Aquaculture 11:1-12

Hill IR, Matthiessen P, Heimbach F (1993) Guidance document on sediment toxicity tests and bioassays for freshwater and marine environments. SETAC Press, Pensacola, FL

His E (1996) Embryogenesis and larval development in Crassostrea gigas: experimental data and field observations on the effects of tributyltin compounds. In: Champ M, Seligman PF (eds) Organotin. Chapman \& Hall, London, p 239-258

His E, Maurer D (1988) Shell growth and gross chemical composition of oyster larvae (Crassostrea gigas) in the field. Aquaculture 69:185-194

His E, Maurer D, Robert R (1983) Estimation de la teneur en acétate tributyle-étain dans l'eau de mer par une méthode biologique. J Mollusc Stud 12A:60-68

His E, Beiras R, Seaman M (1999) The assessment of aquatic contamination: bioassays with bivalve larvae. Adv Mar Biol 37:1-178

Holland DL, Hannant PJ (1973) Addendum to a micro-analytical scheme for the biochemical analysis of marine invertebrate larvae. J Mar Biol Assoc UK 53:833-838

Irving HMNH (1977) Dithizone. Analytical sciences monograph No. 5. The Chemical Society, London

Kersten M, Förstner U (1989) Speciation of trace elements in sediment. In: Batley GE (ed) Trace element speciation analytical methods and problems. CRC Press, Boca Raton, p 246-309

Langston WJ, Bebianno MJ, Burt GR (1998) Metal handling strategies in molluscs. In: Langston WJ, Bebianno MJ (eds) Metal metabolism in aquatic environments. Chapman \& Hall, London, p 219-283

Lartiges S (1994) Analyse et devenir de pesticides organophosphorés et organoazotés dans l'environnement aquatique. Thèse de doctorat, No. 1155. Université de Bordeaux I

Livett EA (1988) Geochemical monitoring of atmospheric heavy metal pollution: theory and applications. Adv Ecol Res 18:65-177

Lourens JM, Vonck AP, Guchte CV, Hartnack J, Stronkhorst J (1995) Sediment toxicity testing of lightly contaminated dredged material in the Netherlands. J Aquat Ecosyst Health 4: 271-275

Luoma SN (1995) Prediction of metal toxicity in nature from bioassays: limitations and research needs. In: Tessier $\mathrm{A}_{\text {, }}$ Turner DR (eds) Metal speciation and bioavailability in aquatic systems, Vol 3. John Wiley \& Sons, Chichester, p 609-646

Melzian BD (1990) Toxicity assessment of dredged materials: acute and chronic toxicity as determined by bioassays and bioaccumulation tests. In: Alzieu C, Gallenne B (eds) Proceedings of the international seminar on environmental aspects of dredging activities. Goubault Imprimeur SA, Nantes, p 49-64

Miller BS, Pirie DJ, Redshaw CJ (2000) An assessment of the contamination and toxicity of marine sediments in the Holy Loch, Scotland. Mar Pollut Bull 40:22-36

Mouneyrac C, Amiard JC, Amiard-Triquet C (1998) Effects of natural factors (salinity and body weight) on cadmium, copper, zinc and metallothionein-like protein levels in resident populations of oysters Crassostrea gigas from a polluted estuary. Mar Ecol Prog Ser 162:125-135 
Olafson RW, Olsson PE (1991) Electrochemical detection of metallothionein. Methods Enzymol 205:205-213

Pavicic J, Skreblin M, Kregar I, Tusek-Znidaric M, Stegnar P (1985) Formation of inducible Cd-binding proteins in selected organs and developmental stages of Mytilus galloprovincialis. J Etud Pollut 1984:699-705

Pavicic J, Skreblin M, Kregar I, Tusek-Znidaric M, Stegnar P (1994) Embryo-larval tolerance of Mytilus galloprovincialis, exposed to the elevated seawater metal concentrations. 1. Toxic effects of $\mathrm{Cd}, \mathrm{Zn}$ and $\mathrm{Hg}$ in relation to the metallothionein level. Comp Biochem Physiol 107: 249-257

Pierard C (1995) Détermination des composés polychlorobiphényles dans l'environnement sédimentaire marin et estuarien. Thèse de doctorat, No. 1346. Université de Bordeaux I

Ringwood AH (1991) Short-term accumulation of cadmium by embryos, larvae, and adults of an Hawaiian bivalve, Isognomon californicum. J Exp Mar Biol Ecol 22:55-66

Ringwood AH, Brouwer M (1995) Patterns of metalloprotein expression in oyster embryos. Mar Environ Res 39: 101-105

RNO (Réseau National d'Observation de la Qualité du Milieu Marin) (1984) Colonne d'eau (statistiques 1er semestre 1982). In: Anonymous (ed) Bulletin du R.N.O. no 19. Min Environ, Paris and Centre Nat Exploit Océans, Brest, p 75-78

RNO (Réseau National d'Observation de la Qualité du Milieu Marin) (1995) Les contaminants dans la matière vivante. In: Anonymous (ed) Surveillance du milieu marin. Min Environ, Paris and Inst Fr Rech Exploit Mer, Nantes, p 9-24

Editorial responsibility: Otto Kinne (Editor),

Oldendorf/Luhe, Germany
Roesijadi G (1992) metallothionein in metal regulation and toxicity in aquatic animals. Aquat Toxicol (NY) 22: 81-114

Roesijadi G, Hansen KM, Fuentes ME (1995) Cadmiuminduced expression of metallothionein and suppression of RNA to DNA ratios during molluscan development. Toxicol Appl Pharmacol 133:130-138

Roesijadi G, Hansen KM, Unger ME (1996) Cadmiuminduced metallothionein expression during embryonic and early larval development of the mollusc Crassostrea virginica. Toxicol Appl Pharmacol 140:356-363

Roesijadi G, Hansen KM, Unger ME (1997) Metallothionein mRNA accumulation in early developmental stages of Crassostrea virginica following pre-exposure and challenge with cadmium. Aquat Toxicol (NY) 39:185-194

Stebbing ARD (1982) Hormesis - the stimulation of growth by low levels of inhibitors. Sci Total Environ 22:213-234

Thompson JAJ, Cosson RP (1984) An improved electrochemical method for the quantification of metallothioneins in marine organisms. Mar Environ Res 11:137-152

UNEP/RAMOGE (United Nations Environment Programme/St RAphaël MOnaco GEnes) (1999) Manual on the biomarkers recommended for the MED POL Biomonitoring programm. UNEP, Athens

Viarengo A, Nott JA (1993) Mechanisms of heavy metal cation homeostasis in marine invertebrates. Comp Biochem Physiol C 140:355-372

Woelke CE (1972) Development of a receiving water quality bioassay criterion based on the 48-hour Pacific oyster (Crassostrea gigas) embryo. Wash Dep Fish Tech Rep 9: $1-93$

Submitted: October 2, 2000; Accepted: October 30, 2001 Proofs received from author(s): April 12, 2002 